\title{
A QUASI EXPERIMENTAL STUDY TO EVALUATE THE EFFECTIVENESS OF VIDEOTAPED INSTRUCTION ON HARMFUL EFFECTS OF TELEVISION VIEWING AMONG SCHOOL CHILDREN AGED BETWEEN 11-14 YEARS STUDYING IN SELECTED SCHOOL, SRI GANGANAGAR, RAJASTHAN Mrs. Kiranpreet Kaur Dhillon ${ }^{1}$ Mrs. Kavitha.K ${ }^{2}$ ${ }^{1}$ Office Administrative Assistant ,MD Distribution, North York, Ontario ,Canada \\ ${ }^{2}$ Staff Nurse, Govt.Primary Health Centre, Kaithari Nagar Madura iTamilnadu Corresponding Email: kiranpreetbutter@gmail.com
}

\begin{abstract}
-
Introduction-:Man is a social animal and socializing plays an important role in keeping ourselves concerned about others in neighborhood and close relations. Television is the window of the world. The glamour and glory of television has attracted all sectors of society. It has literally hypnotized the children.
\end{abstract}

Material and Method: The study was conducted at Good Shepherd Public School, Sri Ganganagar.

Population refers to the entire aggregation of sample that meets the designated criteria.

The target population is the aggregate about which the researcher would like to make generalizations.

In this study it refers to the male and female school children aged between 11-14 years.

In this study it refers to the male and female school children aged between 11-14 years and who fulfills the inclusion criteria.

Result: Regarding source of information in the experimental group 24(60\%) children received information from family and friends, 6(15\%) received information from mass media $10(25 \%)$ from educational programme and none of them from health professional. In the control group $28(70 \%)$ children received information from family and friends, $8(20 \%)$ received information from mass media, $4(10 \%)$ from health professional and none of them from educational programmes.

Conclusion-:The mean difference between the post- test knowledge scores in the experimental and control group was computed by unpaired _t ${ }^{6}$ test. The experimental group mean post-test knowledge score was 25.75 and control group mean post-test knowledge score was 19.42 with the standard error was 0.48 . The calculated 't 'value $\mathbf{1 3 . 1 8}$ which was greater than the table value at 78 degree of freedom (at 0.05 level of significance).

Keyword: assess, educational modules, School Children Aged Between 11-14 Years. 
Today's young children are exposed to an abundance of sedentary activities. The most of sedentary activities. The most studies sedentary behaviour is television (TV) viewing including TV and movie watching, followed by using the computer, and playing video games.

The introduction of $\mathrm{TV}$ in the 1950 's , it has remained as an important part of family life, especially in families with children, even though video games and computers have grown in popularity and availability over the past decades.

\section{MATERIAL AND METHOD:}

A Quasi experimental pre-test posttest control group design was used as a research design in this study as there is a need to conduct generalized assessment of the knowledge of School Children regarding Harmful effects of television viewing.

Pre-test is conducted for Experimental and Control Groups followed by Videotaped instruction for the Experimental group and then post-test was conducted on 8th day for both the groups.

Pre Test

The structured knowledge questionnaire was used to collect data from the school children at Good Shepherd Public School, Sri Ganganagar, after obtaining permission from authority and consent from the subjects. The children were grouped into Experimental $(n=40)$ and control $(n=40)$ group. The investigator used to collect data from 5-10 children per day.

\section{Implementation of Videotaped}

instruction

Followed by pre-test, to the Experimental group, Videotaped instruction was given by the investigator in groups for a period of 45 minutes by using appropriate audio visual aids in English language.

\section{Post Test}

The structured knowledge questionnaire was used for post-test. Post test data was collected on 8th day in both Experimental and control groups.

\section{SUMMARY:}

This chapter deal with the type of research approach used the setting of the study, the population, sampling technique, sample selection, the inclusion and exclusion criteria, the development of the tool, collection of data, pilot study, procedure of data collection and plan for data analysis. So it is the mirror of the research, shows how the investigator utilized the research steps and methods to carry out the study.

RESULT: DISTRIBUTION OF DEMOGRAPHIC VARIABLES 
Table 1: Comparison of Knowledge scores of Pre-test, Post-test I \& Post-test II and

\section{F value of between Group I, Group II \\ \& Control Group}

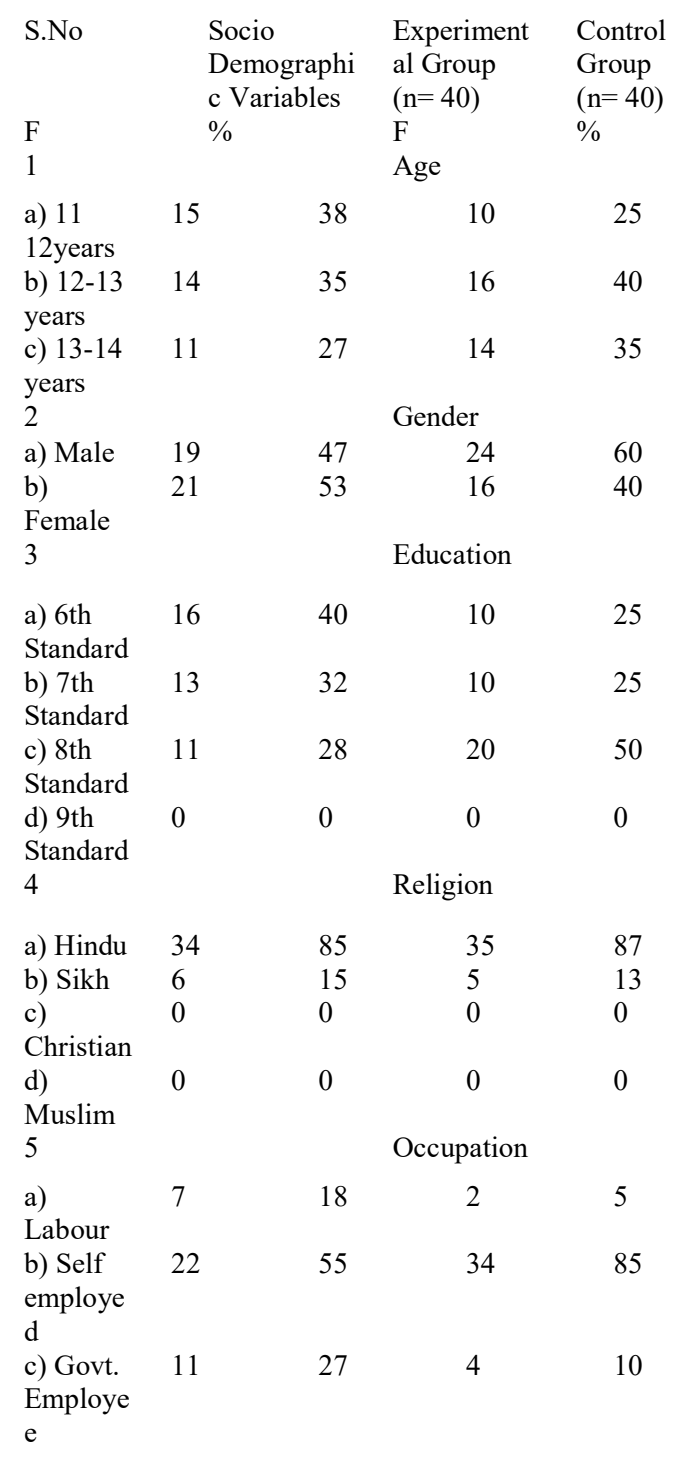

\section{DISCUSSION:}

The findings of the study have been discussed with reference to the objectives and hypothesis stated. The findings in the demographic characteristics and effectiveness of Videotaped Instruction on Harmful Effects Of Television Viewing among school children studying in Good Shepherd Public School at Sri Ganganagar.

\section{CONCLUSION:}

The study was under taken to evaluate the effectiveness of Videotaped Instruction among School children regarding harmful effects of television viewing at Good Shepherd Public School, Sri Ganganagar, Rajasthan. The study involved quasi experimental, pre-test and post-test control group design, with nonprobability sampling technique in which purposive sampling method was used to draw the samples. The size of sample is 40 school children in experimental and control group and selection of the samples were done based on inclusion and exclusion criteria.

\section{REFERENCES-:}

01. Television viewing habits and their effects among high school children in the urban field practice area of mamata medical college.

02. Mohammad Ali Morowatisharifabad, MasoudKarimi, and Fatemeh Ghorb anzadeh Watching television by kids: How much and why.

03. Bates, A. W. (1983). Adult learning from educational television: The 
Open University experience. In M. J. Howe (Ed.), Learning from television: Psychological and educational research. London: Academic Press

04. .Television use in early childhood and academic chievement in eighth grade:examining the moderating effects of parental involvement and program content.
05. HasanuddinNuru*, NoppawanPiaseu, SukriPalutturi, Rasdin, Zaenal,RiniMustamin, FardianaMamang Review Article; Does televisionviewing make children obese? a review.

06. Television and Media Literacy in Young Children: Issues and Effects in Early Childhood KamaruzamanJusoff (Corresponding author) 